\title{
MORPHOMETRICAL ASPECTS OF ADULTS OF Gratiana spadicea (KLUG) (COLEOPTERA, CHRYSOMELIDAE) FROM SOUTHERN URUGUAY*
}

\author{
PONCE DE LEÓN, R., ${ }^{1}$ FAILLA, G. ${ }^{1}$ and MORELLI, E. ${ }^{2}$ \\ ${ }^{1}$ Laboratorio de Zoología Invertebrados, Facultad de Ciencias, Tristán Narvaja 1674, Montevideo 11200, Uruguay \\ ${ }^{2}$ Sección Entomología, Facultad de Ciencias, Tristán Narvaja 1674, Montevideo 11200, Uruguay \\ Correspondence to: Rodrigo Ponce de Léon, Laboratorio de Zoología Invertebrados, Facultad de Ciencias, Tristán \\ Narvaja 1674, Montevideo 11200, Uruguay, e-mail: rodrigo@fcien.edu.uy \\ Received August 12, 1997 - Accepted July 27, 1998 - Distributed September 10, 1999
}

(With 2 figures)

\begin{abstract}
Morphometrical data of pronotum, elytra, and total length of adult males and females of a Gratiana spadicea population from southern Uruguay are given. Descriptions and illustrations of aedeagus and spermatheca are provided for the first time. Females were significatively larger than males in total length. The coefficient of variation of the aedeagus measures ranged from $3.7 \%$ to $7.7 \%$, and those of the spermatheca from $4.1 \%$ to $11.2 \%$. The best value for the coefficient of determination was obtained for the reciprocal regression $(1 / \mathrm{Y}=\mathrm{a}+\mathrm{bX})$ of the total length of the aedeagus versus the length from the apex to the basal region of the median lobe.
\end{abstract}

Key words: Chrysomelidae, Morphometrics, Gratiana, Uruguay.

\section{RESUMO}

\section{Aspectos morfométricos de adultos de Gratiana spadicea (Klug) (Coleoptera, chysolelidae) do sul do Uruguai}

Dados morfométricos do pronoto, do elitra e do comprimento total de machos e fêmeas adultos de uma população do sul do Uruguai são apresentados. A primeira descrição e ilustrações do edeago e da espermateca são fornecidos. Em termos de comprimento total, as fêmeas são significativamente maiores do que os machos. O coeficiente de variação das medidas do edeago variou de 3,7\% a 7,7\%, e o da espermateca, de $4,1 \%$ a $11,2 \%$. O melhor valor para o coeficiente de determinação foi obtido para a regressão recíproca $(1 / \mathrm{Y}=\mathrm{a}+\mathrm{bX})$ do comprimento total do edeago versus o comprimento do apex à região basal do lobo mediano.

Palavras-chave: Chrysomelidae, morfometria, Gratiana, Uruguai.

\section{INTRODUCTION}

Gratiana spadicea (Klug) is one of the best known neotropical crisomelid cassidines due to its valuable role in the biocontrol of the weed Solanum sisymbriifolium Lamarck (Solanaceae) (Hill \& Hulley, 1995). Its trophic and reproductive biology as well as its anatomy have been studied in populations of Argentina (Frers, 1925; Mata \& Aravena, 1926), Brazil (Becker \& Frieiro-Costa, 1987, 1988; Becker \& Romanowski, 1986) and Uruguay (Kvasina \& Ponce de León, 1985). Nevertheless, cytogenetic and dynamics of populations of this species are little known (Becker \& Freire, 1996; González \& Pereyra, 1992; Kvasina \& Ponce de León, 1988). This is probably

\footnotetext{
* Dedicated to Miriam Becker (Universidade Federal do Rio Grande do Sul, Brazil).
} 
due to the fact that there are few morphometrical and zoogeographical data available for an easy identification.

Therefore, in the last 15 years there has been an attempt for the use of morphometrical aspects of the genitalia of this group in order to designate specific and/or populational characters (Cabrera \& Noriega, 1983, 1989; Morelli et al., 1994).

In this paper, we present the results of the first morphometrical study of adults of $G$. spadicea of a population from southern Uruguay, including the first description of its internal genitalia. This study was done with samples taken from the same locality than those of previous works (see González \& Pereyra, 1992; Kvasina \& Ponce de León, 1985, 1988).

\section{MATERIAL AND METHODS}

Specimens of G. spadicea ( 25 males and 25 females) were collected manually on leaves of a single plant of the weed S. sisymbriifolium at Paso del Horno, Sauce, Department of Canelones,
Uruguay. Sampling took place on the $30^{\text {th }}$ December 1994 during an hour in the morning.

Linear measures of external structures and aedeagus were taken following Morelli et al. (1994) and measures of the spermatheca according to Cabrera \& Noriega (1983), with the aid of an ocular micrometer in a Nikon SMZ 10 stereomicroscope. Drawings were made with the aid of a camera lucida. Statistical analysis was performed with the package STATGRAPHICS 5.0, significance tests (Welch aproximation to the $t$-test) were done for a probability lesser than 0.05 , and D'Agostino test for departure from normality was applied according Zar (1984). All measures are given in milimeters. The specimens were deposited in the Entomological Collection of the Facultad de Ciencias (Montevideo, Uruguay).

\section{RESULTS}

\section{Description of the genitalia (Figs. 1a, b)}

Aedeagus (Fig. 1a) long and slender, with an important notch in the phalobase; median lobe curved and with a cuneiform apex.

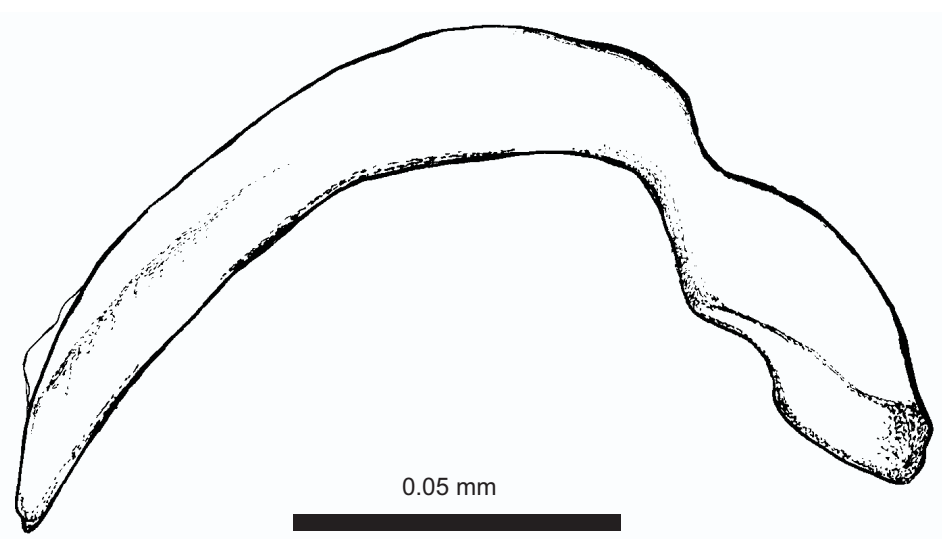

(a)

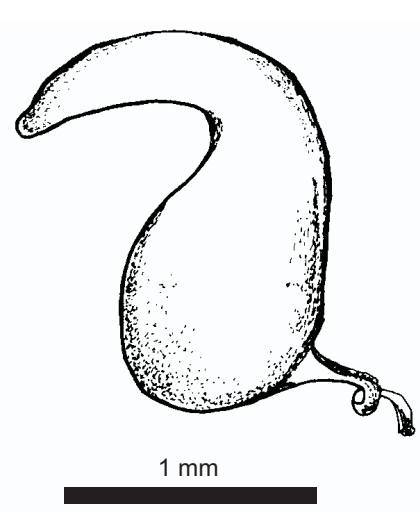

(b)

Fig. 1 - Internal genitalia of Gratiana spadicea (Klug) from southern Uruguay in lateral view. (a) Aedeagus. (b) Spermatheca.

Spermatheca (Fig. 1b) with suboval nodulus, progressively widening to the base and narrow on the cornus; short and curved neck; small and pyriform cornu toward the neck curvature; long and slender ramus, with simple turns, and placed laterally in the base of the nodulus.

\section{Morphometrical data (Tables 1, 2)}

All data showed a normal distribution (variance to mean ratio ranged between 0.039 and 0.136 ). Females were significantly larger than males in total length $(t=3.796)$. In females the coefficient of variation of the pronotum, elytra, and total length 
were mainly lower than those in the males. The best value for the coefficient of determination value $\left(\mathrm{r}^{2}=77.5 \%\right)$ was obtained from the reciprocal regression $(1 / \mathrm{Y}=\mathrm{a}+\mathrm{bX})$ between the aedeagus total length versus the distance from the apex to the basal region of its median lobe. The measures of the aedeagus showed lower coefficient of variations, which ranged from $3.7 \%$ (total length) to
$7.7 \%$ (phalobase length), than those of the spermatheca, ranging from $4.1 \%$ (nodulus length) to $11.2 \%$ (cornus width). In average, the ratio between the distances from phalobase to aedeagus apex and from the apex to the basal region of the median lobe $(\mathrm{bd} / \mathrm{da})$ was $1.39\left(\mathrm{~s}^{2}=0.009\right)$. The average of the ratio between the width and the length of the female pronotum $(\mathrm{w} p / l p)$ was $1.63\left(\mathrm{~s}^{2}=0.007\right)$.

TABLE 1

Measurements ( $\overline{\mathbf{x}}$, average; $\mathrm{s}^{2}$, variance) of the imagines (F, females; M, males) of Gratiana spadicea from southern Uruguay (le, length of the right elytra; lp, length of the pronotum; tl, total length; we, width of the right elytra; wp, width of the pronotum).

\begin{tabular}{|c|c|c|c|c|c|c|}
\hline & F range & $\overline{\mathbf{x}}$ & $s^{2}$ & M range & $\bar{x}$ & $\mathbf{s}^{2}$ \\
\hline lp & $2.00-2.40$ & 2.14 & 0.082 & $1.80-2.20$ & 1.97 & 0.100 \\
\hline wp & $3.10-3.70$ & 3.47 & 0.188 & $2.90-3.50$ & 3.23 & 0.186 \\
\hline le & $4.50-5.50$ & 5.14 & 0.500 & $4.10-4.90$ & 4.52 & 0.576 \\
\hline we & $1.90-2.70$ & 2.34 & 0.324 & $1.90-2.30$ & 2.10 & 0.173 \\
\hline tl & $6.30-7.50$ & 7.05 & 0.534 & $5.50-6.60$ & 6.16 & 0.840 \\
\hline
\end{tabular}

TABLE 2

Measurements ( $\overline{\mathbf{x}}$, average; $\mathbf{s}^{2}$, variance) of the internal genitalia (S, spermatheca; A, aedeagus) of Gratiana spadicea from southern Uruguay ( $\mathrm{da}$, distance between the phalobase and the aedeagus apex; $\mathrm{db}$, distance between the apex and the basal region of the median lobe; dc, distance between the apex and the basal region of the median lobe plus length of the phalobase; lcr, length of the cornus; In, length of the neck region; Ip, length of the phalobase; wcr, width of the cornus; Ind, length of the nodulus; wnd, width of the nodulus; wp, width of the phalobase).

\begin{tabular}{|c|c|c|c|c|c|c|c|}
\hline $\mathbf{S}$ & Range & $\bar{x}$ & $\mathrm{~s}^{2}$ & $\mathbf{A}$ & Range & $\bar{x}$ & $\mathrm{~s}^{2}$ \\
\hline ln & $0.11-0.15$ & 0.13 & 0.010 & da & $1.65-1.90$ & 1.75 & 0.470 \\
\hline ler & $0.13-0.16$ & 0.14 & 0.012 & db & $1.14-1.37$ & 1.26 & 0.125 \\
\hline wcr & $0.07-0.10$ & 0.09 & 0.008 & lp & $0.63-0.89$ & 0.74 & 0.128 \\
\hline Ind & $0.24-0.28$ & 0.26 & 0.009 & wp & $0.43-0.48$ & 0.45 & 0.013 \\
\hline wnd & $0.16-0.19$ & 0.18 & 0.007 & dc & $1.77-2.15$ & 2.00 & 0.212 \\
\hline
\end{tabular}

\section{DISCUSSION AND CONCLUSIONS}

The variation of the measures of the internal genitalia of $G$. spadicea, in particular those of the spermatheca, were independent from those of the external structures in the population studied. Furthermore, measures of spermatheca and aedeagus were not correlated mainly because of the high level of variation in the former. This is a common trait in Coleoptera according to Iablokoff-Khnzorian (1974, 1977). Nevertheless, Morelli et al. (1994) found in the chrysomelid cassidine Metriona elatior a lower variation in the measures of the female external structures and spermatheca than in the measures taken from males. However, this may have been due to the fact that were few specimens measured; only 10 males and 8 to 9 females.

In order to obtain a more accurate knowledge of the intra and interpopulation morphometrical variations of $G$. spadicea future works will be necessary. In this way, may be useful to take into account the shape and measures of the aedeagus and the ratios $d b / d a$ and $w p / l p$ of specimens from distant and biogeographically dissimilar realms. 
Acknowledgements - Special thanks are given to Dr. Eduardo Petitpierre and to an anonymous reviewer for the constructive comments on the manuscript. This study was partially granted by CSIC/UR (Uruguay).

\section{REFERENCES}

BECKER, M. \& FREIRE, A. J. P., 1996, Population ecology of Gratiana spadicea (Klug), monophagous cassidinae on an early successional Solanaceae in southern Brazil. Chrysomelidae Biology, 2: 271-287.

BECKER, M. \& FRIEIRO-COSTA, F., 1987, An analysis of the fate of eggs of Gratiana spadicea (Klug, 1829) (Coleoptera: Chrysomelidae: Cassidinae) in relation to the position in the ootheca. Rev. Bras. Zool., 4(3): 195-205.

BECKER, M. \& FRIEIRO-COSTA, F., 1988, Natality and mortality in the egg stage in Gratiana spadicea (Klug, 1829) (Coleoptera: Chrysomelidae), a monophagous cassidine beetle of an early successional solanaceae. Rev. Bras. Biol., 48(3): 467-475.

BECKER, M. \& ROMANOWSKI, H. P., 1986, The female internal reproductive organs of Gratiana spadicea (Klug, 1829)(Col.: Chrysomelidae: Cassidinae): morphology and histology. Rev. Bras. Biol., 46(1): 149-157.

CABRERA, N. \& NORIEGA, A., 1983, Contribución al conocimiento de los Crisomélidos argentinos I: Valor taxonómico de la espermateca en el género Disonycha Chevrolat. Revta. Soc. Ent. Argent. 42(1-4): 9-16.

CABRERA, N. \& NORIEGA, A., 1989, Contribución para el conocimiento de los Crisomélidos argentinos II: Valor taxonómico de la espermateca y octavo esternito en el género Disonycha Chevrolat. Rev. Soc. Ent. Argent., 46(1-4): 147-156.

FRERS, A., 1925, Metamorfosis de coleópteros argentinos. Physis, 7: 82-86.
HILL, M. \& HULLEY, P., 1995, Biology and host range of Gratiana spadicea (Klug, 1829) (Coleoptera: Chrysomelidae: Cassidinae), a potential biological control agent for the weed Solanum sisymbriifolium Lamarck (Solanaceae) in South Africa. Biol. Control, 5: 345-352.

GONZÁLEZ, A. \& PEREYRA, L., 1992, Análisis citogenético de Gratiana spadicea (Coleoptera: Chrysomelidae). Bol. Soc. Zool., 7: 90.

IABLOKOFF-KHNZORIAN, S. M., 1974, Remarques sur les genitalia femelles des coléptères et leur armure. Ann. Soc. Ent. Fr., 10(2): 467-486.

IABLOKOFF-HNZORIAN, S. M., 1977, Notes sur l'édéage des Coléptères Nouv. Rev. Entomol., 6(3): 229-238.

KVASINA, M. \& PONCE DE LEÓN, R., 1985, Nuevos aportes a la biología de Gratiana spadicea (Klug, 1829) (Coleoptera: Chrysomeliae) y su relación con la planta huésped Solanum sisymbriifolium (Solanaceae). Bol. Soc. Zool., 3: 9-15.

KVASINA, M. \& PONCE DE LEÓN, R., 1988, Estudio citogenético de Gratiana spadicea (Klug, 1829) (Coleoptera: Chrysomelidae): un potencial agente biocontrolador de Solanum sisymbriifolium (Solanaceae). Spheniscus, 7: 1-6.

MATA, A. \& ARAVENA, R., 1926, Metamorfosis de un coleóptero del género Gratiana. Rev. Soc. Ent. Argent. 1: 31-34.

MORELli, E., GONZALEZ-VAINER, P. \& PONCE DE LEÓN, R., 1994, Descripción de los estadios de Metriona elatior (Klug, 1829) (Coleoptera: Chrysomelidae) en Solanum elaeagnifolium Cavanilles (Solanaceae) del Uruguay. Elytron, 7: 147-155.

ZAR, J. H., 1984, Biostatistical Analysis. Prentice Hall, New Jersey, $718 \mathrm{p}$. 